\title{
Commodification and Adventure in New Zealand Tourism
}

\author{
Paul Cloke \\ University of Bristol, University Road, Bristol BS8 1SS, UK \\ Harvey C. Perkins \\ PO Box 84, Lincoln University, Canterbury, New Zealand
}

This paper discusses the ways in which the commodification of adventure in tourism has increasingly become implicated in the production and consumption of tourist places. It examines the notion of adventure in tourism and the changing nature of commodification in postmodern and 'post-tourist' times. The rise of adventure tourism in New Zealand is used as an example of how adventure has been commodified. A survey of tourist brochures for adventure tourism attractions in New Zealand reveals some of the particular characteristics of adventure which are being incorporated into commodity form for tourists. These characteristics include place, spectacle, embodied experience and memory. Although aware of the limitations of using textual evidence from brochures, the paper concludes that Best's (1989) society of the commodity and the society of the spectacle are clearly significant in New Zealand. Sign exchange is also important in the commodification of adventure although it is concluded that places and practices are as yet rarely eclipsed by adventure signification.

\section{Introduction: The Importance of Commodified Adventure}

The 'moulding [of] culture for tourism and tourists, and [the] moulding of tourism and tourists for culture' (Craik, 1997: 122) has become a very significant nexus in the study of the economic and cultural transformation of places. This paper focuses on a particular facet of these moulding processes: the ways in which the commodification of adventure in tourism is increasingly implicated in the (re)production and consumption of tourist places. We argue that new forms of commodified adventure have become a crucially important part of contemporary tourism in some places. Using adventure tourism in New Zealand as a case study we therefore discuss the connections between consumption and place promotion, and the ways in which they influence the representation and experience of place, and the formation of cultural identity in different places.

The New Zealand case is an interesting and important one. Promotion of New Zealand overseas by New Zealand tourism agencies has traditionally included a mix of fresh, unspoilt scenic environment and a unique Maori culture (Ryan, 1997). While adventure activity, such as mountaineering in the South Island, has comprised a small part of the mix since the 19 th century, more recently aspects of nature and adventure tourism have been given a much more prominent emphasis in promotional activities. In one sense this has led to a set of more complex and multiple images of New Zealand, as illustrated in Figure 1 which represents a popular postcard depicting the various 'elements' of a New Zealand tourist experience.

In another sense, however, adventure has begun to take on a centrally impor- 


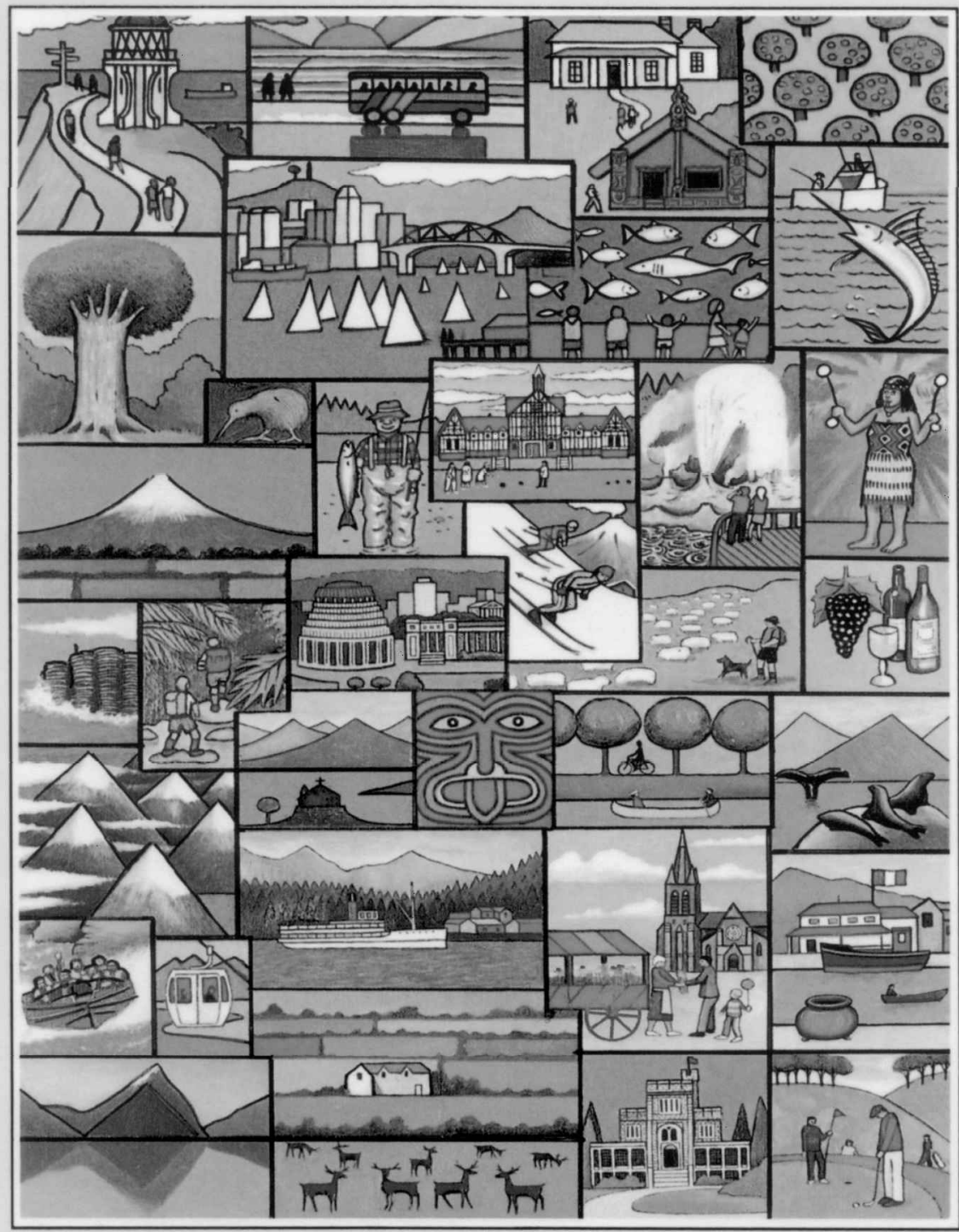

\section{NEWAotearoa}

Figure 1 Postcard summary of New Zealand's attractions

(Image by Ted Scott, Fotofile Ltd, Titirangi, Auckland, New Zealand (http: //www.yellowpages.co.nz/for/fotofile/) 
tant role. As we have discussed elsewhere (Cloke \& Perkins, 1998), in a wide-ranging imaging of New Zealand called The New Zealand Way and a recent reimaging as $100 \%$ Pure New Zealand, the Government and its promotional advisers have sought to emphasise the thrilling and adventurous nature of the place (Figure 2). This strategy has filtered through into international tourism marketing. Images of the jet boat or the bungy jump have become frequently used as advertising logos for New Zealand tourism as a whole, and adventure tourism attractions figure prominently in tourist guides and other travel literature relating to New Zealand. The New Zealand Tourist Board made heavy use of the slogan 'New Zealand is Adrenaline Country', and provided tourist inquirers in the UK and elsewhere with a specific Adventure brochure in which the great outdoors is inextricably interconnected with adventure:

Synonymous with adventure, action and adrenaline, New Zealand is where it all began. Experts on how to make the most of the great outdoors, New Zealanders are eager to share it with the rest of the world ... New Zealanders are justifiably proud of their reputation for inventing some of the most original and thrilling activities known to mankind. (NZTB, 1998: 1)

Potential overseas visitors to New Zealand are therefore presented with anticipatory images and ideas about the adventurousness of the place.

It is our contention that the commodification of adventure in tourism in New Zealand has been aided by the conditions of postmodern tourism which emphasises the dramatic reshaping of the economy and culture of our time (Dann, 1998; Meethan, 1996; Pretes, 1995). Urry's (1990) 'post-mass tourist' (abbreviated to 'post-tourist') is the central actor here. The post-tourist's objects of desire are sign values relating to novelty, the attainment of cultural capital, and intense thrill and spectacle. These objects of desire are provided by new forms of commercial venture providing niche products which permit tourists to move away from what was previously perceived as 'mass' tourism, and to gain access to specialised activities often in far-flung places. In this way, for example, the movement of young people to New Zealand for niched nature or adventure tourism may be seen as part of the wider postmodern market-place. Forms of 'mass' and 'niche' tourism are by no means mutually exclusive, and so adventure tourism attractions will benefit from 'mass' tourism into New Zealand as well as from 'niche' tourism by particular groups. Post-tourists are thought to be aware of the staged nature of the experiences of tourism, but are equally ready to enjoy playing the role of tourists (Crick, 1995). They are therefore drawn to the spectacle and other attractions of commodified place-related tourism.

Adventure has, of course, always been a facet of travel and tourism. Simmel $(1950,1959)$, for example, used the terms stranger and adventurer in his interpretation of the ways in which travellers or leisure seekers identify themselves. Tourists step out of the regularity of everyday life, which they know intimately, into places, practices and experiences which are ephemeral and largely unknown. Simmel's strangers have become familiar in tourism studies (Jokinen \& Veijola, 1997). Simmel's adventurers, though, have been less familiar. This is surprising because adventure is now iconic in attempts to emphasise alterity in the supply of tourism activities and experiences in some places. It has become an essential 


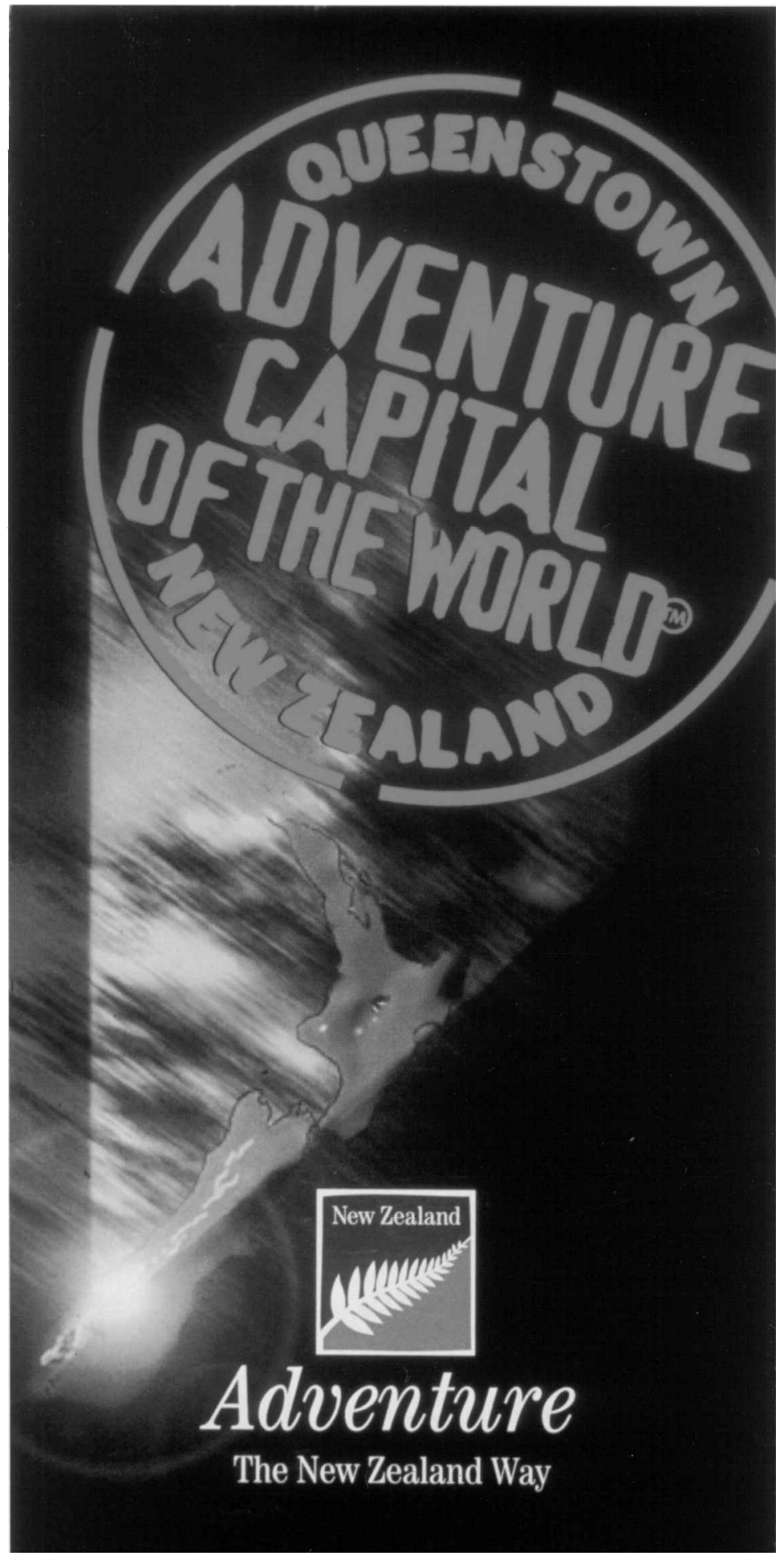

Figure 2 New Zealand Way's Adventure brochure 
segment of the tourist identity to be increasingly catered for in a formal way. There has thus been a marked rise in the provision of adventurous attractions in the great outdoors of, for example, New Zealand, Australia, and British Columbia, where the attraction of bungy jumping, white water rafting, jet boating and the like has provided a new impetus for tourism (Cloke \& Perkins, 1998).

The importance of adventurous tourism lies not only in the rise of a tourist phenomenon, but also in the interconnections between commodified adventure and the changing nature of place and culture. As Squire (1994: 11) has argued 'forging integrated understandings of tourism necessitates focusing attention on the processes through which particular places and/or experiences become vested with tourist meanings'. Commodification, then, has place-related impacts. In support of this perspective, Ritzer and Liska (1997), relying on Ritzer's (1996) theoretical work on the 'McDonaldization' of society, have suggested that the transformations occurring in tourism constitute a part of advanced modernity, a 'McDisneyization'. They imply that tourist sites have become increasingly places where people can seek out tourist experiences which are predictable, efficient, calculable and controlled. The branding of such sites offers the guarantee of known satisfaction. In some ways, McDisneyisation appears at odds with the escapism (Frisby, 1992; Rojek, 1993) of adventurous tourism. But then, adventure has many forms and it is not restricted to particular places. Many will find a visit to Disneyised attractions 'adventurous', and therefore operators of alternative adventurous sites will both wish to distance themselves from the hegemonic imagery and style of Disney and adopt tried and tested Disney techniques of branding, marketing, pricing, ancillary product sales, safety, staff (or 'cast') performance and the like. It might be anticipated, then, that the commodification of adventure may introduce an air of Disney's efficient and controlled predictability to adventurous pursuits and the places in which they are set.

As adventurous tourism becomes commodified, then, so do the places in which that tourism is sited. Place change will involve important social and cultural changes as well as physical impacts. Morris (1995: 180-1), reflecting on her experience of tourism in Australia, summarises such impacts:

Wherever tourism is an economic strategy as well as a money-making activity, and wherever it is a policy of state, a process of social and cultural change is initiated which involves transforming not only the 'physical' (in other words, the lived) environment of 'toured' communities, and the intimate details of the practice of everyday life, but also the senses of relations by which cultural identity (and therefore, difference) is constituted for both the tourist and the toured in any given context.

The rest of this paper discusses the nature of this commodification process: first by interrogating a range of theoretical ideas about the relationship between touristic commodity forms and wider society, and then in a brief empirical study of the commodification of adventure tourism attractions in parts of New Zealand.

\section{Tourism and the Commodification of Place}

The rise of adventure tourism attractions in a country such as New Zealand is intimately associated both with the translation of places, and physically chal- 
lenging and exciting recreational activities, into commodities. The emergence of new tourist attractions represents part of a continuing progression of the social relations of capitalism dictated by profit motives and revolving around the nexus of exchange (Watson \& Kopachevsky, 1994). Accordingly, the commercialisation of adventure tourism places and activities is accompanied by many of the tried and tested techniques by which private profit is maximised. What is especially interesting, however, is the way in which the demands of capitalism are associated with changes to the nature of place, culture and social experience, changes to the commodity form itself. A number of perspectives on the commodification of place and culture in tourism have been advanced and we shall now briefly review those parts of that work that are relevant to our argument.

An interesting perspective on the changing form of tourism commodities can be drawn from Best's (1989) analysis of how the society of the commodity has been transformed into the society of the spectacle and even the society of the simulacrum (see Cloke, 1993). In the society of the commodity, commodification represents an inversion of exchange value over use value. Objects become commodities when they take on an exchange value over and above their use values and are able to be traded, putting them into the realm of the quantitative. In the transformation of the society of the commodity into the society of the spectacle, commodification becomes a product of a way of living where individuals consume a world made by others rather than producing their own. Here, spectacle is a complex notion which refers at the simplest level to mass media society but more deeply to the vast institutional and technical apparatus of late capitalism, which obscures the experience of continuing alienation. Spectacle takes us from Marx's being into having to Debord's (1983) having into appearing. Here, image takes precedence over material objects.

A further transformation in commodity form was suggested by Baudrillard (especially 1983a, 1983b), whose analyses of postmodern cybernetic society pointed to exchanges carried out in the arena of signs, images and information. In such a society, he argued, commodification involves the absorption of the object into the image, thereby allowing exchange to take place in semiotic form. Commodities reflect sign-exchange values and are intricately connected with the structural logic of the signs concerned. The focus here for producers and consumers is on the conspicuous nature of social meaning, and the commodity will often involve abstract signifiers which can be unrelated to the reality of the commodified place, practice or object. As the commodity is eclipsed by the sign, so it implodes into its imagery, and is characterised by simulacrum.

The three-fold transformation suggested by Best, from commodity through spectacle to simulacrum, offers a framework with which to interpret the commodification of tourist places and practices. The society of the commodity, with its inversion of exchange value over use value, is a very familiar idea in the understanding of commercial tourism, which trades on just such exchange values relating to doing different things in different places for relaxation and /or stimulation; escape and/or adventure. Equally the idea of spectacle is by now a widely accepted facet of production and consumption processes in tourism. In these terms, tourism involves the visual consumption of signs or spectacles which are produced at sites, both urban and rural, and are 'transformed into aestheticised spaces of entertainment and pleasure' (Meethan, 1996: 324). Tour- 
ism in the society of the simulacrum implies a step further into hyperreality (Dann, 1998) and has as its focus the consumption of representative commodities which have no form or basis in reality. These commodities are sights and sites which are 'representations of representations or signs of signs'. Natural and semi-natural attractions are divided from artificial ones but the difference lies not in natural versus man-made, but in whether the attraction serves some original function before it becomes touristic' (Pretes, 1995: 4).

Much of the discussion of spectacle and simulacrum has been linked with questions of how commodification has transformed local communities and cultures. Cohen (1988: 372-3), for example, noted three such impacts, the first of which is that tourism is said to lead to 'commoditization' of areas of local community life. In this process " colourful" local costumes and customs, rituals and feasts, and folk and ethnic arts become tourist services or commodities, as they come to be performed or produced for touristic consumption'. The meaning of cultural products and of human relations changes, such that they eventually become meaningless and because 'local culture can be commoditized by anyone, without the consent of the participants, it can be expropriated, and the local people exploited' (Cohen, 1988: 372).

Second, 'commoditization is said to destroy the authenticity of local cultural products and human relations' (Cohen, 1988:372). It is replaced with a surrogate, covert 'staged authenticity' in which contrived cultural events are staged for tourists. Third, "'staged authenticity" is said to thwart the tourist's genuine desire for authentic experiences' (Cohen, 1988:372). Implicit in this analysis is the view that tourism operators mislead tourists into accepting contrived attractions as authentic, thus creating a 'false touristic consciousness' (Cohen, 1988: 373). In concluding his analysis, Cohen shows how the corollary of these assumptions is that 'commoditization, engendered by tourism, allegedly destroys not only the meaning of cultural products for the locals, but paradoxically, also for tourists' and that tourism is therefore a 'colossal deception' (Cohen, 1988: 373).

This perspective and many of the associated assumptions outlined by Cohen have been used in attempts to theorise the commodification of place in tourism. Britton (1991), for example, placed heavy emphasis on the commodification of leisure and tourism in capitalist society. In doing so he borrowed the notion of the 'culture industry' of the Frankfurt School who traced the gradual bureaucratisation, rationalisation and mechanisation of social life and wrote of the ways in which the culture industry 'defused critical consciousness and provided a key means of distraction and stupefaction' (Best, 1989:29). Put in these terms, Britton (1991) argued that the commodification of place is a central element of much leisure and tourism development and suggested that 'certain places and sites (with their landscapes, social practices, buildings, residents, symbols and meaning) achieve the status of tourist sights because of their physical, social, cultural and commercial - attributes' (Britton, 1991: 462).

Influenced by Lefebvre (1976), Britton emphasised that discrete and categorised landscapes are set aside as leisure spaces to satisfy the functional necessity for recreation as an important element in the reconstitution of human capital. These leisure spaces are overlain by elements of the tourist production system tourist attractions which are sights and sites of significance to tourists and in 
many ways are unrecognisable as such except for one critical element - their markers.

These are any information or representation that labels a sight as a sight... They may take the form of brochures, guide books, on-site plaques, reproductions (photographs, art prints, souvenirs), educational material, television travel programmes, reviews in lifestyle magazines, or the incorporation of the sight into cultural symbols or national icons. (Britton, 1991: 463)

Markers and the tourist attractions which they represent are produced in three ways: first by coopting existing cultural attractions or places of interest for touristic purposes; second, by creating new, purpose-built attractions and third, by combining tourist rehabilitation of socially and economically depressed regions. These attractions (their specific sites and their surrounding regions) are commodified first as the tourist industry works to connect its products, and thereby enhance their meaning, to already existing, often attractive public goods (e.g. townscapes or rural landscapes); and second by assimilating originally non-touristic ventures into the tourist system (e.g. shopping centres) thereby imparting touristic meanings to specific places and sites. In Britton's (1991) view, the primary mechanism for imparting these meanings (apart from the effect of propinquity) is advertising, packaging and market positioning, that is, by selling places in such a way as to suggest that the tourist will get more than in reality the place can offer. Such place marketing and Cohen's (1988) interpretation of 'commoditization' is nicely illustrated, for example, by Hughes' (1992) study of the Scottish Tourist Board's selling of the Highlands for tourism purposes (but see also Cloke, 1993 and Corkery \& Bailey, 1994). Hughes suggests that the Board has created a sanitised and picturesque mythical Highlands quite unlike the real poverty-stricken and oppressed Highlands of history. Tourists are told stories of this place which blur the boundaries between history and fiction.

While not entirely rejecting all elements of the views of commodification in tourism put forward by the writers discussed above, other researchers write in ways which challenge the notion that commodification is a process that works itself out in the same way in all places as part of capitalism's ever-spreading embrace. In short, they doubt the usefulness of the universalising elements of the neo-Marxist critique of capitalism and its underpinning ideas of false consciousness and domination. Rather, they believe that commodification should be viewed as the commercialisation of cultural performance and the places in which it occurs. Commodification, therefore, is negotiated by actors in particular places to meet particular situations and requirements and as a consequence differs in form and content from place to place. In this view, most tourist places can be interpreted as being more or less affected by the capitalist market economy, so the challenge for social scientists is to interpret the great variability in impact of market influences on those places and the experiences to be had there. They also need to interpret how places are socially constructed and reconstructed in an emergent and ongoing fashion by a purposeful set of actors either in conflict or co-operation with each other.

In support of this view, Stymeist (1996) (but also see Watson \& Kopachevsky, 
1994: 652), in his anthropological study of Vilavilairevo (Fijian firewalking), contributes to debates about commodification and authenticity by arguing that:

As is the case regarding the economic impact of tourism, it cannot be assessed or even meaningfully discussed in an all-encompassing, global sense. Questions concerning the nature, validity, authenticity, commoditization, or semiotics of cultural performances in tourism can only be approached situationally and then only with a thorough grounding in the history of the event, ceremony or ritual in question, along with an understanding of its place in the larger scheme of things and the processes of its emergence as a part of the tourist's experience. (Stymeist, 1996: 2)

Stymeist concludes that 'any assessment of Fijian firewalking must be cognisant of the institution's history and its place in the lives of its participants, past and present' (Stymeist, 1996: 13). He shows clearly that while this cultural performance had been thoroughly commercialised, with performances being transferred from traditional village sites to tourist hotels, it did not mean that it had become meaningless and phoney. Although the event is no longer performed by the members of a folk community for themselves but is enacted only for tourists in exchange for money . . . as an expression of their cultural heritage, the event is widely appreciated and highly regarded by many Fijians' (Stymeist, 1996: 13).

The adoption of Stymeist's situational approach to the study of commodification in tourism does not necessarily imply that researchers will always reach such optimistic conclusions (Philp \& Mercer, 1999). Johnston and Edwards (1994), for example, discussed the settings in which mountaineering has become significantly commodified (e.g. in Nepal, Pakistan, Bhutan, and in some parts of the mountains of Argentina, Europe and North America) and traced the patterns of its growth and eventual transformation from adventure and exploration to a commodified Alpine eco-tourism. In this process, mountaineering was transformed from a relatively informal European 19th-century recreational pastime, in which a few participated in a limited number of places using unsophisticated equipment and forms of transport, into a highly organised globally-based touristic, technocentric and commercialised enterprise. The authors showed how climbing technology has transformed the sport, how mountaineering, particularly in the Himalayas because of the scale of the mountain environment, has demanded the participation of local residents, often as porters, with its attendant social and economic impacts. They also discuss the ways in which mountaineering has been placed at the nexus of commercial interests (through the medium of advertising, sponsorship, and mountain guiding) and government regulatory and tax-gathering activities (through permit management and sales). The story told by Johnston and Edwards describes a growing swarm of climbers, laden with high-tech equipment, descending on mountain areas (particularly in Nepal) and then ascending the local mountains at considerable cost, occasionally to themselves in the form of accident or death, but mainly to local communities and the natural environment. The natural environmental degradation includes hillside denudation, littering on a grand scale and serious pollution problems as a result of inadequate human waste disposal and treatment arrangements (AFP, 1999; Simpson, 1998). 
This is an important study because the authors discuss the nature of adventure tourism and the commodification process as it occurs and is negotiated in particular locations. Also important is the reference the authors make to the contested nature of the commodification process in the Himalayas. In social terms Johnston and Edwards discuss the mountaineer from the host perspective: as an outsider whose presence instigates complex social, cultural, economic and environmental repercussions. They retell the story told by mountaineer Bruce Bunting of a Himalayan village priest (or gomchen) in Bhutan who said 'I always pray to the local deities for snow when you outsiders come to our valley, so you will go away. You use all our firewood and show little respect for our traditions' (Smith, 1991: 82 quoted in Johnston \& Edwards, 1994: 469). The fact that commercialisation of cultural performances and associated tourist places is contested underscores the possibility that commodification may be limited by local actors seeking to ascribe new or different meanings to cultural performances and places (Meethan, 1996). Game (1991), for example, discusses such a contest, which is still ongoing, in the area of Sydney, Australia, known as Bondi beach. She outlines the battles between those who would 'revitalise' Bondi and make it an international tourist attraction and local residents who, while they are not unified in their desires for the beach area, want to resist this extra degree of commercialisation and keep Bondi for Australians.

This view of the commodification of tourist places brings us into line with Massey's (1995) account of the contested nature of place meaning and identity. She noted that:

The description, definition and identification of a place is thus always inevitably an intervention ... into the (re)telling of the historical constitution of the present. It is another move in the continuing struggle over the delineation and characterisation of space-time ... [I]t may be useful to think of places, not as areas on maps, but as constantly shifting articulations of social relations through time; and to think of particular attempts to characterise them as attempts to define, and claim coherence and a particular meaning for, specific envelopes of space-time... [T] he identity of places, indeed the very identification of places as particular places, is always in that sense temporary, uncertain, and in process. (Massey, 1995: 188-90)

Commodification may be seen in these terms as one of a number of processes at play in the creation of place that must be investigated in specific time-space locations at the intersection of the global and local. Increased tourism-related commercialisation, or new forms of commercialisation of a place, will not therefore destroy it in the sense of making the place meaningless; rather, this commercialisation will take the form of a new importation around which local and global actors (including tourists; tourist investors, marketers and operators; and locals) will compete and/or cooperate in the ongoing and emergent construction of the meaning of the place.

Our objective in the remainder of this paper is to discuss the commodification associated with the rise of adventure tourist attractions in New Zealand in terms of these differing theoretical perspectives on commodification. 


\section{The Rise of Adventure Tourism in New Zealand}

The development of tourism in New Zealand has been extensively charted, especially by Pearce (1990, 1992, 1993, 1995; Pearce \& Simmons 1997; but also see Collier, 1994; Hall \& Kearsley, 2001; Page, 1989; Perkins \& Cushman, 1993, 1998; Perkins \& Thorns, 2001). Although tourism has had an economic presence in New Zealand since the early 19th century it was only in the 1980s that a surge of overseas visitor arrivals transformed tourism into a vital sector of the national economy. The visitor surge has led to, among other things, a booming demand for outdoor recreational activities, including those often associated with adventure tourism - heli-skiing; hot air ballooning; jet-boating; white water canoeing, rafting, sledging and surfing; solo and tandem sky diving; tandem parascending and hang-gliding; black water rafting (on underground rivers); and conventional or helicopter bungy jumping (Berno et al. 1996; Cloke \& Perkins, 1998; Devlin, 1995; Hobbs, 1996; Johnston, 1992; Kearsley, 1993; MacIntyre \& Roggenbuck, 1998; McLauchlan, 1995; Page \& Meyer 1996; Ryan, 1997; Wane, 1995/1996). It has recently been estimated that the 1.5 million visitors to New Zealand in 1994 took part in 5 million adventure activities (Greenaway, 1996), and these rates of activity are thought to be rising steeply (Page \& Mayer, 1996). In a recent study of advertising brochures for places and attractions associated with adventure tourism in New Zealand, (Cloke \& Perkins, 1998) these activities were found to be located throughout the country's two main islands, although there was a clustering of sites around the tourist centres of Queenstown, Rotorua and Taupo, and the 'gateway' cities of Auckland and Christchurch.

Despite the growth of adventure tourism activities, they are not the most popular of those undertaken by international tourists in New Zealand. As is the case for New Zealanders' recreational patterns (Devlin, 1993, 1995; Devlin \& Booth, 1998; Veal et al., 1998), visitors to the country are most often to be found spending their leisure time engaging in such relaxed activities as eating in restaurants, general sightseeing, shopping, taking city walks and socialising with family and friends (Tourism New Zealand, 2002). This suggests that while some overseas tourists visit New Zealand to concentrate solely on adventurous leisure activities such as mountaineering, many, if they engage in adventurous activity at all, do so as part of a wider recreational repertoire. This spreading of the tourist dollar is of considerable value to the tourism industry and support for it has been seen in recent attempts at place promotion in New Zealand which have tried to show how tourists visiting a particular region may participate in a range of urban and rural passive and adventure recreation activities (Schöllman et al., 2000). In Queenstown, for example, marketed as a centre for adventure tourism, visitors participate in a wide range of activities only some of which could be classified as adventurous. Berno et al. (1997) found that only a minority of international and domestic visitors to the town participated in adventure activities. The Queenstown Promotion Board's 1993 study (quoted in Berno et al., 1996) found that only $9 \%$ of visitors undertook jet boating, $8 \%$ bungy jumping and $3 \%$ went rafting. In support of this finding, Berno et al. (1997) found that in November 1993, of the total of 651 tourists surveyed in their study, $473(72 \%)$ had not participated in an adventure activity on their visit to Queenstown. Of those who did participate, 
( $n=178) 62 \%$ had done one activity, $22 \%$ had done two activities and only $16 \%$ had done three or more. The most frequently chosen activities were jet boating, bungy jumping, white water rafting, helicopter and fixed wing scenic flying with only a few taking part in parapenting, sky diving, kayaking, and parasailing and hang-gliding. The majority of participants were in the 20 to 35 age range with respondents over the age of 45 considering themselves 'too old' to take part. Tourists from Singapore, Japan and other East Asian countries were most likely to participate. Domestic tourists were significantly less likely to be seen in these activities. They believed that the activities were too costly, indicating also that they thought the activities were for 'tourists' (overseas visitors) rather than for 'locals'.

Seen in these terms, the use of adventure as a central element in New Zealand's tourism marketing is an attempt to emphasise alterity. Tourists visiting New Zealand may participate in activities available in many other countries but while doing so they may also, if they wish, take part in adventure activities available in few other places or perhaps only in New Zealand. Adventure, as a marketing strategy, is being used to make New Zealand stand out as offering unique opportunities.

Five factors are significant in understanding the rise and commodification of adventure tourism in New Zealand. First, outdoor recreation in New Zealand has held a central cultural position over the years, and from the late 19th century this has provided opportunities for the extension and commodification of domestic activities which today are also sold to overseas visitors (Cloke \& Perkins, 1998; Devlin, 1993; 1995: Devlin \& Booth, 1998; Devlin et al., 1995; Hall \& Kearsley, 2001; Higham, 1996b; Kearsley, 1990; Perkins \& Gidlow, 1991). This begs the questions of why New Zealanders and visitors engage in adventure activities and what is it about those experiences that lend themselves to commodification. This in turn raises questions about the connections and transactions between nature and recreational participation that lie at the heart of the adventure tourism experience, a subject which has been little researched in New Zealand. An important exception is the work of McIntyre and Roggenbuck (1998) who conducted a multi-phasic analysis of nature/person transactions during a commercial black water rafting trip in the Waitomo Caves. They studied recreationists' focus of attention, moods, on-site nature experiences and perceptions of risk and competence in order to describe the changing, unfolding nature of an intense and extraordinary adventure recreation experience. McIntyre and Roggenbuck (1998:401) concluded that such recreational activities are based on rich and complex person-environment transactions. Challenging situations such as jumping down an underground waterfall 'created mildly unpleasant feelings of nervousness and apprehension that can also be exciting'. The degree to which activities were pleasant or not was influenced by perceptions of risk.

Passive contemplation combined with low level activity (floating through the cave in the dark) induced feelings of peace, calm and enjoyment when nature was viewed as benign and non-threatening. Each of these situations resulted in variation in the intensity of arousal and relaxation. (McIntyre \& Roggenbuck, 1998: 419-20)

There is therefore much in the outdoor adventure experience that may be 
commodified (Walle, 1997). As we have indicated elsewhere (Cloke \& Perkins 1998), and as supported by Haddock (1993) and McIntyre and Roggenbuck (1998), in commodified adventure tourism, guides and outdoor recreational leaders assess absolute risk and implement safety procedures to ensure the real risk to participants is limited. In this relatively safe situation (Page \& Meyer, 1996; The Press (Christchurch), 9 September 2000: 6; 27 September 2000: 12) they can manipulate participants' perceived risk to create a sense of recreational challenge and excitement.

The second important feature of adventure tourism in New Zealand has been the setting aside of land for conservation purposes (Booth, 1993; Hall, 1988; Pearce \& Booth, 1987; Perkins et al., 1993; Shultis, 1989, 1991). Some 30\% of New Zealand's land area is allocated to public management, including conservation and recreational use (New Zealand Tourism Board and Department of Conservation, 1993). In this way some of the most spectacular and scenic locations in New Zealand have at the same time been protected from sprawling tourist-related development, yet made available for specific adventurous activities. Adventurers thus benefit from unspoilt natural settings in which to pit themselves against the forces of nature. Of course, in some ways, these activities will themselves be regarded as spoilers of unspoilt landscapes and environments.

Third, key innovations in transport and technology are also linked with the rise of adventure tourism. Jet boat technology, for example, was invented by a New Zealand farmer, Bill Hamilton, in 1953, as a response to the need for fast and manoeuvrable navigation of shallow, braided, swiftly flowing rivers. Similarly, the A J Hackett company have been major innovators in the technology of bungy apparatus. Technological developments have therefore allowed the introduction of new recreational activities which were quickly commercialised for tourists (e.g. bungy jumping, parapenting) or have allowed well-established domestic recreational activities (e.g. jet boating, rafting) to become more easily commercialised as part of adventure tourism.

Fourth, there have over recent years been strong attempts to provide 'brand' images for New Zealand as a nation. In June 1993, for example, an integrated marketing campaign was masterminded by Saatchi and Saatchi to establish a uniquely recognisable brand identity. The resultant campaign company, The New Zealand Way (1993) - branded New Zealand as young, fresh, unspoilt and innovative, thereby providing a strong cultural raison d'être for adventure tourism alongside the more obvious economic one. The recently established $100 \%$ Pure New Zealand campaign builds on these themes. In this way, adventure tourism attractions have often acted as signifiers of the New Zealand brand both in particular landscapes and further afield. For example, many advertisements for travel from the UK to New Zealand carry with them an image of the jet boat as the principal advertising logo. The success of such branding attempts may be measured, in part, by the way overseas visitors speak about New Zealand and their reasons for visiting it. Michael Palin, late of Monty Python's Flying Circus, in his role as traveller and television personality, recently visited New Zealand as part of the BBC production Full Circle. His televised sojourn through the country conveyed a number of images of New Zealand and its people: Maori culture, wildlife, student cultural life at the University of Otago, scenic landscapes and adventure tourism activity. Interestingly, however, when Palin was interviewed 
on New Zealand television about his motives for visiting the country, he emphasised his primary interest in what he saw as a dominant image held of New Zealand in the UK: widespread participation in dangerous adventurous outdoor recreational activity. Terry Pratchett, English fantasy writer and former journalist, on an Australasian tour to publicise one of his books, had a similar story to tell:

If he wrote a book based on New Zealand the characteristics he would focus on would be the nature of New Zealanders. He said New Zealand was the home of dangerous sports and the difference between being alive and dead in New Zealand was small. Pratchett said New Zealanders seemed 'hell-bent on breaking their necks in any interesting way. (O’Hanlon, 1998: 6)

While Pratchett's views are a caricature of New Zealand society and the adventure-based recreational opportunities that are available to New Zealanders and visitors alike, both he and Palin illustrate the influence of the adventure-oriented image of New Zealand that has been promoted in the UK over recent years.

The fifth and final factor important to an understanding of the rise and commodification of adventure tourism in New Zealand is an increasing concern about the environmental impacts of tourism growth. While in many cases tourism growth has had limited influence on the outdoor or wilderness recreational opportunities available to New Zealanders, impacts are beginning to be felt. Outdoor recreation management agencies are increasingly concerned that if good management approaches are not applied then negative impacts could increase very significantly (Coughlan, 1997a and b; Coughlan \& Kearsley, 1996; Devlin 1993, 1995; Devlin \& Booth, 1998; Devlin et al., 1995; Higham, 1996a, b, 1997a, b, and c, 1998; Higham et al., 1996; Kearsley et al., 1997; Kearsley \& Higham 1997; Kearsley \& O’Neill, 1994).

Good examples of activities in which environmental impacts are becoming obvious include fresh water angling and tramping (backcountry walking). In some readily accessible and well-known sites (e.g. rivers, lakes, camping grounds and walking tracks), which were until 20 years ago largely the preserve of New Zealand recreationists, tensions have arisen as overseas anglers and trampers have taken advantage of these resources, sometimes with the aid of professional guides and encouraged by readily available tourist guidebooks and other publicity information. These crowding-related tensions and the accompanying processes of displacement are further exacerbated when wealthy overseas tourists challenge existing backcountry culture and use expensive modes of transport (e.g. helicopters and jet boats) and professional guides to gain access to backcountry wilderness areas without the effort of walking in and 'roughing it' in the ways traditionally expected by New Zealand outdoor recreationists (Coughlan, 1997b; Kearsley \& O'Neill 1994). There are signs of growing resistance to these developments (PANZ, 1997).

Additionally, international tourists, too, report limited but important unsatisfactory backcountry experiences due to crowding (Higham, 1996a, b, 1997a, b, and c, 1998; Higham et al., 1996). It would be too simplistic to suggest, however, that these problems are only confined to local-international visitor interactions in the process of touristic commodification. Wealthy New Zealanders also take 
advantage of now readily available four-wheel-drive vehicles, jet boats and helicopters to circumvent the effort once required to gain access to backcountry wilderness, thus complicating the nature of the situation being addressed here.

\section{Commodification of Local Adventure Tourism Places}

We now turn to our case study of the commodification of local adventure tourism places which is based on an interpretation of over 300 different advertising brochures collected by the authors in New Zealand in 1994 and 1998. The brochures relate to places and attractions associated with adventure tourism, and were obtained systematically either as the authors visited the adventure tourism attractions or from tourist information offices in a number of centres in the North and South Islands. While adventure tourism opportunities are available in many parts of the country, for the sake of brevity our main focus will be on sites in the Queenstown area of the South Island and, to a lesser extent, other key tourist centres such as Taupo in the North Island. If New Zealand is described as the adventure tourism capital of the world, then Queenstown is frequently promoted as the adventure tourism capital of New Zealand (and therefore, by implication of the world - see Figure 2).

The brochures were analysed using content analysis and interpretative semiotic analysis, and both are employed in this paper. Indeed, that which follows uses relatively few of the brochures to present an indicative (rather than representative) account of some of the most significant attributes of commodification being portrayed. Dann (1996), Goss (1995), Pearce (1982) and Selwyn $(1990,1996)$, have argued that it is legitimate and important to make use of promotional texts in order to substantiate theoretical considerations.

The brochures used in this survey had a specific promotional purpose, namely to advertise particular places and attractions to tourists already in New Zealand. They were typically aimed at visitors to information centres in key gateways or regional centres and at visitors already in a localised area such as Queenstown. As such their purpose also fits within the framework outlined by Uzzell (1984); that is, as representations designed to transform 'first order' images of particular destinations into texts with ideologically significant 'second order' meanings for tourists. The brochures, therefore, play a dual role. First, they aim to draw tourists to particular attractions, by using images and words which in some way idealise the site and activity concerned. Second, they add to the development of wider place-myths and place-images, providing visitors with narratives about the characteristics and meanings associated with the places concerned. Naturally, some tourists will never pick up a brochure; others will decide where not to visit on grounds (such as competitive pricing) which are not directly influenced by brochures; and yet others will employ tactics of subversion of, or resistance to, texts which are so obviously promotional and propagandist. Despite these obvious discontinuities between representation and consumption, there is a strong argument that brochures are part of the commodification process, especially designed to convey spectacle and sign-exchange values, and of the wider cultural practice of tourism, and to communicate anticipatory expectations about attractions and their meanings. It is against this conceptual and methodological backcloth that the analysis of brochures is used to highlight four attrib- 
utes of commodity form which are significant in these adventure tourism attractions, although these four should be viewed as both indicative and overlapping, rather than constituting discrete categories.

\section{Place}

The first and perhaps most obvious commodity-form is that of place. In the society of the commodity, the simple injunction is to create exchange value beyond use value. Much of what tourists see and do (Cloke \& Perkins, 1998; Perkins \& Thorns, 2001; Urry, 1990), for example, has often been free of charge. Places are visited and sights are seen without direct cost, although service providers will benefit from their charges for travel (coach, car hire) and for subsistence (accommodation, meals). Commodification of place in simple terms therefore means the organisation of a pay-as-you-enter, or pay-as-you-play, attraction. Adventure tourism attractions are often high value, and experienced or consumed in relatively short periods of time (consider the cost per time ratio of a bungy jump, for example), and therefore represent good opportunities for commodifying a particular place.

That which is being 'sold' at these attractions, however, is only partly encapsulated in this simple view of commodity form. The value of particular adventure tourist places extends beyond their role as specific activity sites. In particular, important historic or spectacular scenic features are often part of the commodity package relating both to broad place promotion and to the appeal of specific attractions. Thus, The New Zealand Way's Adventure brochure (Figure 2) made prominent connections between the historic adventures associated with the Queenstown region and the contemporary commodified adventures on offer there:

... it's a small town of people doing exciting things. Its always been that way here, from the first Maori tribes who battled their way over the mountains to find the sacred pounamu (jade), the gold prospectors of yesteryear to the thrillseekers of today. This amazing land of mountains, lakes, rivers and forests is home to some of the most accessible adventures on this planet. (Brochure: Adventure: The New Zealand Way)

These adventurous place commodities spill over into individual attractions. To jet boat on a New Zealand river is one thing; to jet boat down a scenic river steeped in goldmining history is something else. One of the best-known adventure tourism attractions in New Zealand of this sort is the Shotover Jet on the Shotover River near Queenstown. The attraction began operating in 1965 with the slogan:

Jet boat on the river of gold, river of history, river of death, river of glory. (Brochure: Shotover Jet Limited, Queenstown)

And the 1994 brochure emphasised not only the 'rugged shotover canyons' but also that the 'Shotover River is renowned as the world's richest gold-bearing river'. By 1998, the promise was that:

... during your trip you'll learn about the river's gold bearing history and see relics from the past. (Brochure: Shotover Jet Limited, Queenstown) 
In this example and others, the commodity on offer is not merely a jet boat ride. It is the combination of scenic spectacle, historic connection and thrilling ride which is being captured and sold, as if the dangers and imperatives of the goldrush era can be reproduced for visitors, albeit in a sanitised and high-tech form. Here, the commodification of place involves the production of theatre, a place to perform as well as to watch, with local actors taking on the technical roles but each tourist being the star of the show.

Adventure tourism often entails connections with particular types of places. With increasing demand for adventure tourism, new sites are being sought out or even produced as part of the commodification process. So, where there is no convenient bridge at a key scenic site, place has to be commodified in a different way. Taupo, for example, is a highly accessible centre in the North Island for both domestic and overseas tourism, and during the 1990s several adventurous attractions have been established there (including Huka Jet (a subsidiary of Shotover Jet), Rapid Sensations (a rafting company) and Taupo Tandem Skydive). The lack of a suitable bridge for bungy operations has not prevented the commodification of place for this purpose, with Taupo Bungy (Brochure: Taupo Bungy and Scenic Cruises Limited) building 'the world's first purpose built cantilever bungy platform' to permit jumps down a spectacular cliff face beside the Waikato River.

\section{Spectacle}

The society of the spectacle is also in evidence in the commodification of adventure tourism in New Zealand. The image of adventure may be seen to be overtaking the material objects concerned, and the reduction of reality to appearance is manifest in many of the attractions studied. Take almost any of the major adventure tourism attractions, and strong elements of spectacular theatre emerge. This is partly because the activities themselves are dramatic, but also because a show is being staged. A jet boat ride comprises a skilful ride down a prescribed course which is intended to give the sensation of being perilously close to the rocky sides of the river canyon at considerable speed. It entails a dramatic 360 turn (usually at a staged position to permit photography). The driver will deliver speeches - prologue and epilogue - and will often wear some kind of 'costume'. Several 'performances' per day invite comparison with the monotony experienced by actors in a long-running play. Each performance, however, is new for participants, themselves in splashproof costume and engaging the plot for the first time.

Moreover, although these spectacular pursuits are designed to attract paying participants, there is also an important secondary commodification going on in terms of the audience. Many brochures insist that the 'thrill' of adventure can be experienced in watching as well as participating:

Throw yourself off the bridge or watch other people do it - either way Bungy jumping is a different sort of buzz. (Brochure: The Hanmer Connection, Hanmer Springs, Canterbury)

People watching at the spectacle are drawn into the commodity in a number of different ways. Commercially, the free theatre draws them into the shop and café 
facility which increasingly accompanies the attraction. Watching can also draw the spectator into the activity and thus lead to paid participation.

Theorising the society of the spectacle says much about the leisure-seeking proclivities of the times, without necessarily persuading us to accept spectacle as any form of 'narcotic' of capital. The key feature here is the triumph of appearance over reality. The 'experience' of these sites is being imbued with a staged adventurism. Clearly the staging permits different levels of 'danger' for different types of clients - a jet boat ride will attract a more general group of consumers than will rafting, and certainly bungying. Nevertheless, the natural environment is being served up so as to sell sanitised experience - a safe conquering of nature.

\section{Embodied experience}

If places and staged spectacles are key aspects in the commodification of adventure tourism, then so is the selling of particular forms of embodied experience. The adventurer in contemporary tourism is being presented with a series of packaged commodities in which excitement, thrill, fear and overcoming of fear can be purchased as part of an experience of the great New Zealand outdoors. The brochures advertising these attractions make reference to heightened bodily sensation. The brochure, New Zealand Adrenaline Guide, for example, tells readers that 'there's nothing in the world like the buzz you get when you push your body and mind to the limit. Once you experience that full hit of adrenaline, there's no going back.'

The representations of adventure tourism in such brochures adopt forms of language and images from youth culture and theme park in order to promote the embodied experiences of adventure. On the back of the Pipeline Bungy brochure (Pipeline Bungy, Queenstown), for example, the problems of representing such experiences in images and words are skilfully tackled. The narrative of a first-time jumper (Howie) establishes that before the jump there is a need to 'get a bloody life', and that in order to do so, the place to be is 'Queenstown, Nirvana, Mecca, heaven and hell, where everyone's twisted, buzzing, magnetic, on to it'. Once in the right place, Howie experiences the anticipation of his jump:

Wooow, radical road hip, adrenaline eldorado, shitting boulders, act cool, I'M IN. Hey, what's happening, holy shit the PIPELINE! Legendary madness, man, look at these people fly. Tough guys whimper, girls gather strength. What the hell am I doing here.

Then comes the jump itself:

Houston, countdown, TAKEOFF, AAAAARRRGGHHHWWW- AAAAHHOOOOO-YYEEHAA ... AMPING, I'm raging - Nothing compares.

The transition from fear to adrenaline-filled exhilaration - from 'AARH' to 'YEEHAA' - is the essence of commodified adventure. Accompanying images mark a similar journey from wimp to hero, from grimace to grin, from the boring everyday to the conquering alterity which comes from overcoming the forces of nature and hanging out with the big boys and girls.

Such texts obviously beg important questions about the significance of gender amongst commodity consumers (see Cloke \& Perkins, 1998) but they leave little doubt that what is being sold here is embodied thrill, associated with realising 


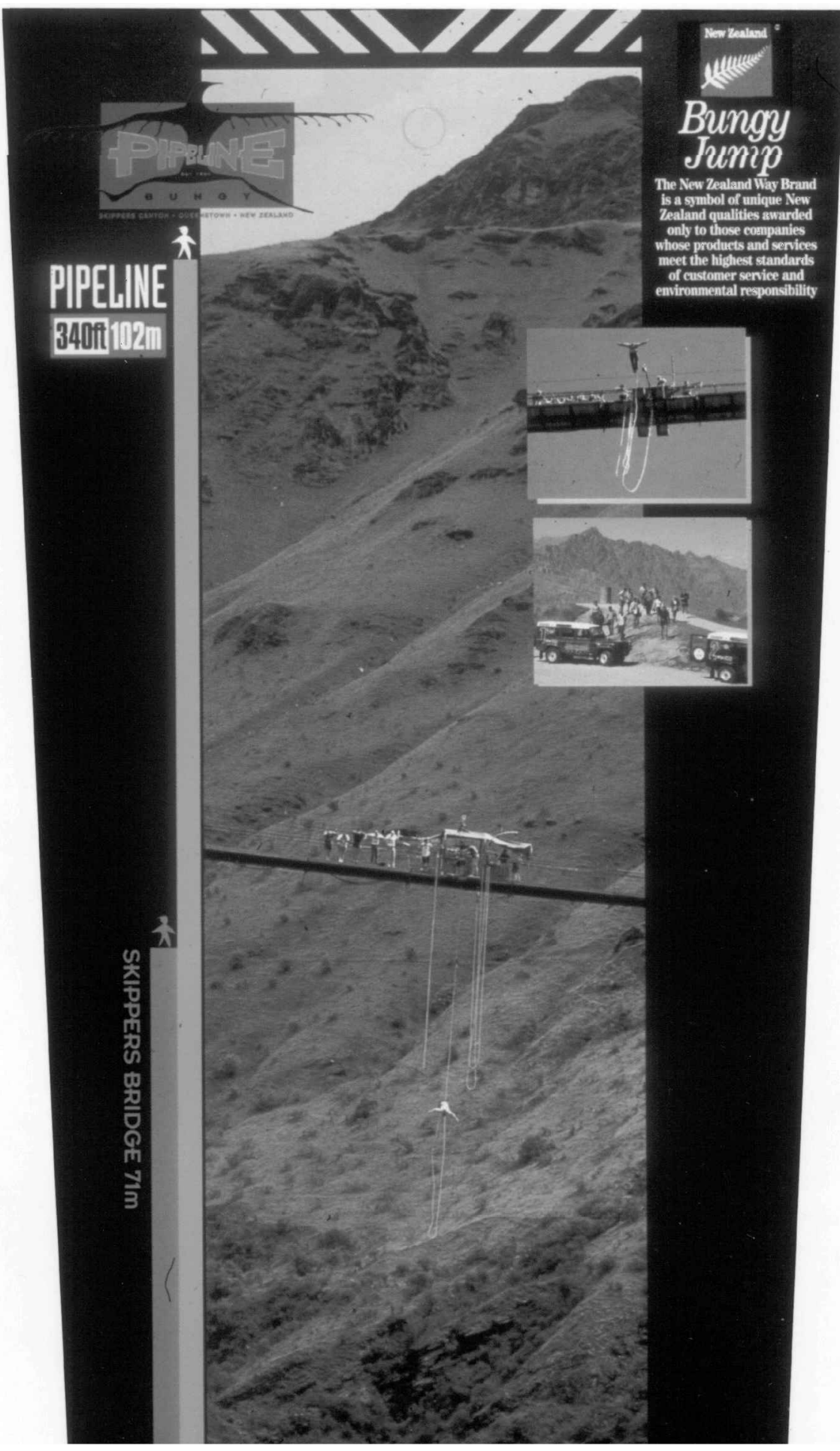

Figure 3 Pipeline Bungy, Queenstown 
personal growth and self-discovery. Walle (1997) has suggested that tourists seek out adventurous practices for self-actualisation and fulfilment in terms of spiritual achievement and learning. The evidence of our survey of brochures points more towards a commodification of sublime thrills, however. Brochures certainly challenge tourists to 'discover a little more of yourself', but greater emphasis tends to be focused on the idea of being 'rewarded with the satisfaction of knowing you can accept a challenge and enjoy the thrill of a lifetime'? (Brochure: Skydive Go Solo, Christchurch). The adrenaline rush from speed and personal daring is crucial here, as post-tourists acknowledge the staged nature of the risk involved, yet happily play the role of tourist-taking-extreme-risk in order to achieve subliminal experiences (Bell \& Lyall, 1998).

\section{Memory}

To the immediate bodily gratification offered by adventurous experiences should be added longer-term dimensions of the commodity form. In order to maximise the profits of the enterprise, operators will invite tourists to buy not only the immediate, but also the souvenirs of the immediate. Consumers are usually offered the opportunity to appropriate the place-experience by taking it home in the form of a print of video photography. With the advent of digital technology, a faster and more flexible range of memorabilia has become available. Digital selection of video frames means that powerful images can be e-mailed back home, for example, or printed onto a T-shirt so quickly that advertisements of the experience can immediately be seen on the streets of New Zealand or on a personal computer anywhere in the world. Adventurous tourists will now often accept the chance to purchase these photographic records of themselves as a kind of transferable story of how they thrillingly overcame nature in New Zealand's great outdoors. Operators will further pander to the commodification of memory by providing certificates to commemorate the successful completion of the activity. Adventure is about achieving something worthwhile; having something to take home with you that is worth (freeze) framing. Even for those who choose not to participate, the natural setting of the adventure tourism site is made into a spectacle by the spectacular feats of others, so photographs record people's achievements in adventure places for future storytelling.

It is notable that the brochures offer very clear anticipatory images of these commodified memories. The Pipeline Bungy brochure (Figure 3), for example, places the jumper in the centre of a vertically expansive image which links sky, pipeline jump-site and river. Other brochures present close-up images of participants (see Figure 4), precursing the eventual photographic record which replaces the figure in the brochure with the tourist himself or herself. Part of the power of the visual text of the brochures appears to be this replacement - the provision of an adventurous thrilling backcloth against which to record your own body, self, memory.

Despite the fact that adventure tourism in New Zealand constitutes something of a 'packaged' experience in a developed and accessible (if often distant) nation, there remains a sense that it is sufficiently differentiated from mass market tourism to provide a memory imbued with spatial and social distinction. As such, the commodification of memories of experiences is firmly part of the new landscape of postmodern tourism, with its niched products appealing to 


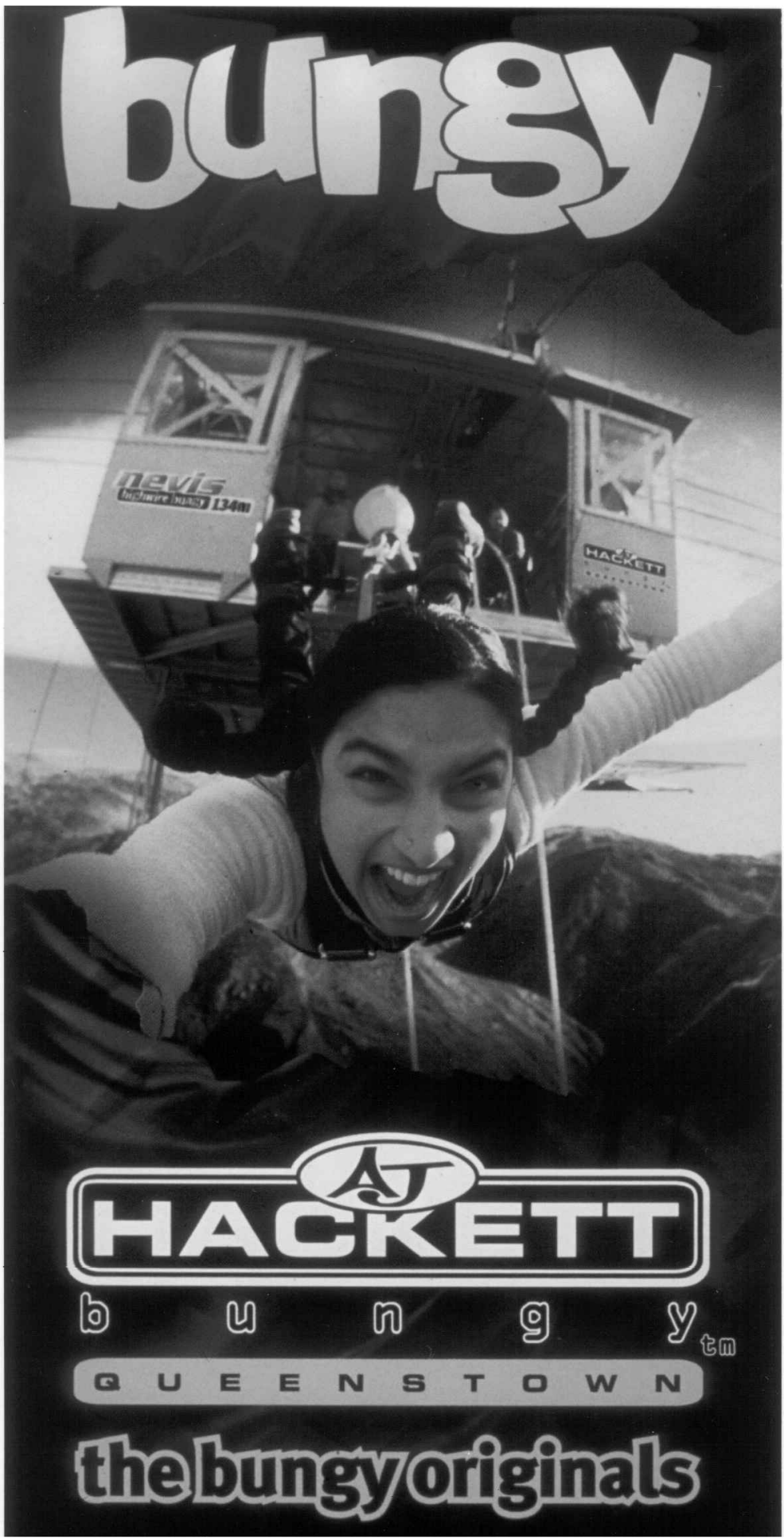

Figure 4 A J Hackett Bungy ${ }^{\mathrm{TM}}$, Queenstown 
discerning and affluent consumers. Munt (1994) discusses the kind of practices used by new middle-class fractions to establish social differentiation and to dissociate themselves from the tourism practices of class fractions below. This involves signalling the distinction of 'other' postmodern tourism. Adventure tourism has a definite part to play in such distinction, a point illustrated by a discussion that one of us had with a group of tutorial students in Bristol. The discussion ranged around consumption issues relating to the ubiquitous nature of the branded T-shirt, and focused on issues of sport and fashion as well as tourism. It transpired that among this particular group, the most admired and sought-after T-shirt was the A J Hackett bungy T-shirt from Queenstown, New Zealand. While some T-shirts did not meet the requirements of 'distinction', this shirt did somehow carry with it the image of practised differentiation identified by Munt. The students claimed that they knew of people who had included New Zealand in their travel itinerary 'just to get that shirt' and that several of them could be seen being paraded about the university (an assertion which was subsequently verified by eight sightings in one day). Interestingly, the T-shirt of distinction is prominent in the visual portrayal of Howie's adventurous transformation in the Pipeline Bungy brochure (on the reverse of Figure 3), albeit in this case with strongly gendered overtones. A 'before' image shows Howie in the shadows of a bungy hero sporting the Pipeline T-shirt, whereas in the 'after' image it is Howie's turn to wear the shirt with pride, and receive the resultant 'adulation'. While the specificity of such examples will change over time, there is nevertheless a strong suggestion that commodity forms that tourists can bring home are integrally interconnected with the commodification of adventure tourism.

\section{Conclusion}

The rise of adventure tourism in New Zealand, as with other countries (notably Australia, Canada and the USA) is closely linked with changes in the emphasis and forms of commodification in tourism. The availability of long-haul air travel has been entwined with an increasing willingness of some tourists to seek out destinations which are further away from home, and which are represented as niche destinations. The significant rise in overseas visitors to New Zealand suggests its status (at least in part) as a niche destination. As The New Zealand Way's Adventure brochure (Figure 2) seeks to reaffirm, 'some say you've got to be adventurous to even get to this place'. That very rise in numbers blurs the distinction between mass and niche tourism, however.

Any analysis of a particular niched theme, such as adventure tourism, must accommodate the multiple elements of tourist consumption in the place concerned. Many visitors, perhaps pursuing more conventional tourism aims of staying with family, driving through scenery, sampling indigenous or culinary culture and so on, will be unaffected by new forms of commodified adventure. Age, health, money, sheer disinclination or even positive resistance will mean that adventure tourism will not be part of the tourist experience of some consumers. For others, adventure is merely part of a wider experience of New Zealand, and they will therefore depart with multiple impressions of the place and its tourism highlights. For yet others, adventure will form a much more significant part in their practice and consumption of tourism in New Zealand. 
Within these multiplicities of consumption, however, we suggest that adventure tourism commodities are becoming increasingly significant in a number of ways. Best's (1989) interpretation of three progressive commodity-societies has some obvious relevance here. So too does Stymeist's (1996) situational approach. Best's society of the commodity is clearly evident in New Zealand's adventure tourism, as operators seek to establish and enhance profitable businesses by creating high exchange values for experiences which can (notably in the case of a bungy jump) be extremely short lived. Promotional brochures are designed to sell these products. They make promises about the guarantee of thrills in a safe environment of acceptable risk. They reflect tried and tested ways of making a profit, featuring predictability, efficiency, and closely controlled consumer experiences. Capitalist rationality follows through into supplementary profit making, via refreshment, photographic and other retail services. Post-tourist consumers recognise these commodity traits, but are willing to proceed in order to gain the distinction of other aspects of the commodified exchange: place, spectacle, embodied experience and memory.

Consistent with Stymeist's suggestion that we take account of the influences of local context in interpretations and evaluations of commodification processes, a discussion of the society of the commodity and its relationship to New Zealand tourism must inevitably lead at some stage to an analysis of the rapid growth of adventure tourism businesses. Typically, the original and often innovative operators have quickly found themselves in competition with alternative providers in the same area. The response has often been to expand the business into other sites or other attractions. Thus, for example, Shotover Jet has expanded its jet-boating operations from its Queenstown base to Huka Jet at Taupo, and even to Fiji. It has also acquired subsidiaries such as the Dart River Jet Safari in Queenstown. Further innovation has come with the packaging of several adventurous experiences together as 'combos' such as the 'Crazy Kiwi' (Brochure: The Crazy Kiwi Combo links Queenstown Rafting with the A J Hackett ${ }^{\mathrm{TM}}$ and Pipeline Bungy operations) or the 'Awesome Foursome' (Brochure: Crack The Canyon, Danes Rafting Company, Queenstown). The collaboration of different companies takes various forms, but can be close in less competitive environments such as Taupo, where the 'Maxbuzz!' group of operators use centralised promotional and booking facilities (Brochure: Taupo Bungy, Taupo Tandem Skydiving and Rock ' $n$ Ropes. It invites tourists to 'get your rocks off!'). Yet more innovation takes the form of new adventurous activities, such as blackwater rafting (for example, Metro Cave Westport and Waitomo Caves, Otorohonga), urban bungy jumps (for example, Bungee Rocket, New Brighton, Christchurch) and urban rap jumping (for example, Adrenaline Adventures, Auckland). As a counter to this discussion about the growth of adventure tourism businesses it is important also to point out that the development of adventure tourism, particularly in remote backcountry sites, is also being contested by some New Zealanders who wish to limit the use and commodification of places and activities once only available to domestic recreationists.

Best's society of the spectacle also appears to be significant in understanding the role of adventure in New Zealand tourism. Again, Stymeist's situational approach can be combined with Best's interpretation to better understand the conjunction of adventure and commodification. One of the key features in the 
growth of adventure tourism in New Zealand is that it has been based on the country's spectacular, relatively unpopulated landscapes and a cultural history of significant local participation in outdoor recreational and related activities. Adventure tourism in New Zealand is based on sites and spectacle which, through participation, observation or even just awareness, significantly influence the experiences of many tourists. The spectacular scenery of mountain, river and gorge has been rendered more attractive by the provision of adventurous spectacle. Landscape thus becomes in part a stage for spectacular adventurous performance, and the operators of the attractions provide the cast and the props so that participants can take centre stage. It is important to acknowledge that the other areas of New Zealand tourism (for example nature tourism) are also responding to the perceived need to promote spectacle, not least as part of the contemporary conversion from informal free-access sightseeing to pay-asyou-participate attractions. The brochures studied in this paper predominantly choose to make an impact on consumers by presenting images of spectacle, be it the unnatural vertical profile of a bungy-jumper or a whitewater raft, the impression of speed given by a jet-boat or helicopter, or the 'I can fly' spectacle of skydiving or parapenting. Many New Zealand tourist businesses now profit, partially or wholly, from these adventurous spectacles.

It is Best's society of the simulacrum which is most controversial, because of its emphasis on sign-exchange values and its suggestion that objects become absorbed into images such that abstract signifiers can emerge which are unrelated to place or practice. On the basis of the brochures studied, it can be argued that elements of sign-exchange values exist in New Zealand's adventure tourism attractions. The direct promotion of New Zealand as an adventurous place (by The New Zealand Way, 100\% Pure New Zealand and others) is an important pointer to adventure as a signifier which moves beyond a particular experience to characterise a place or even a nation. Equally, it can be suggested that for consumers of adventure tourism attractions, the commodity being purchased in not simply a fall, jump or ride but participation in the signs as well as the experiences of adventure, thrill, and conquering of nature's places. Nevertheless, even accepting these suggestions, and noting the tendencies towards McDisneyisation by operators of attractions, it is difficult to conclude that the places and practices of commodities are as yet eclipsed by the adventure sign. To a significant degree, the moorings which tie adventure to particular places, objects and experiences remain in place at these attractions and must be interpreted situationally by both tourists and tourism researchers. The recent introduction of 'virtual' bungy jumping at Te Papa (the Museum of New Zealand), Wellington, does, however, point to the potential for a development of a future society of the simulacrum.

Here it should be acknowledged that ideas of commodity, spectacle and simulacrum cannot ever be fully answered on the basis of representative texts such as brochures. There is no doubt that the graphics and textual design of tourist brochures in New Zealand, as elsewhere, are culturally significant, not least because they unleash powerful discourses which point to a postmodern culture of commodity aesthetics promoting significant objects of desire. To that extent it can be concluded that the intensity of recent commodification has raised the profile of sign values, especially those which signify the affluence, prestige and 
capacity for differentiation inherent in adventure tourism in New Zealand. The brochures, and the signs they exhibit, however, should not be regarded as overriding symbolic structures which shape the passive consumer, and construct him or her as part of the symbolic landscape being represented. Consumers will actively negotiate these signs, cutting across the discursive notions of commodity. Thus gender, class, ethnicity and age are vitally important in understanding the strategies and tactics of those who do, and do not participate in adventure tourism (Mellor, 1991). In practical terms, then, it should be reiterated that how tourists react (or not) to the messages of brochures is just as important as the icons and discourses which carry those messages (Chalfen, 1985). Nevertheless, the images of tourism are important because they establish the boundaries of experience (Dann, 1996); they are the main way of sampling the tourist 'product' in advance, and as such remain a crucial source from which to identify prevailing discursive manoeuvres. The grow th of adventure in New Zealand tourism, then, testifies to the importance of the discourses supported by promotional representatives such as brochures, as well as to the participatory tactics of many tourists themselves.

\section{Acknowledgements}

Paul Cloke acknowledges the support of an Erskine Fellowship in the Department of Geography at the University of Canterbury.

\section{Correspondence}

Any correspondence should be directed to Prof. Paul Cloke, University of Bristol, School of Geographical Sciences, University Road, Bristol BS8 1SS, UK (p.cloke@bris.ac.uk).

\section{References}

AFP (1999) Bottle collection on Everest. The Press (19 March), 14.

Baudrillard, J. (1983a) Simulations. New York: Semiotext.

Baudrillard, J. (1983b) In the Shadow of the Silent Majority. New York: Semiotext.

Bell, C. and Lyall, J. (1998) The accelerated sublime: Thrill-seeking adventure heroes in the commodified landscape. Paper presented to the Practising Places and Tourist Performance Conference, University of Durham, April.

Berno, T., Moore, K., Simmons, D. and Hart, V. (1996) The nature of the adventure tourism experience in Queenstown, New Zealand. Australian Leisure 7 (2), 21-5.

Best, S. (1989) The commodification of reality and the reality of commodification: Jean Baudrillard and post-modernism. Current Perspectives in Social Theory 19, 23-5.

Booth, K. (1993) Recreation on public lands in New Zealand - past, present and future. GeoJournal 39 (3): 299-305.

Britton, S. (1991) Tourism, capital and place: Towards a critical geography of tourism. Environment and Planning D: Society and Space 9, 457-78.

Chalfen, R. (1985) Comment on Uzzell. Annals of Tourism Research 12, $103-6$.

Cloke, P. (1993) The countryside as commodity: New rural spaces for leisure. In S. Glyptis (ed.) Leisure and the Environment (pp. 53-67). London: Belhaven Press.

Cloke, P. and Perkins, H.C. (1998) Cracking the canyon with the awesome foursome: Representations of adventure tourism in New Zealand. Environment and Planning D: Society and Space 16, 185-218.

Cohen, E. (1988) Authenticity and commodification in tourism. Annals of Tourism Research 15, 371-86.

Collier, A. (1994) Principles of Tourism (3rd edn). Auckland: Longman Paul. 
Corkery, C. and Bailey, A. (1994) Lobster is big business in Boston: Postcards, place commodification and tourism. GeoJournal 34, 491-8.

Coughlan, D. (1997a)Constraints on Back Country use. In J. Higham and G. Kearsley (eds) Trails in the Third Millennium, Conference Proceedings. Dunedin: Centre for Tourism, University of Otago.

Coughlan, D. (1997b) Displacement in the New Zealand backcountry: Does it exist? In J. Higham and G. Kearsley (eds) Trails in the Third Millennium, Conference Proceedings. Dunedin: Centre for Tourism, University of Otago.

Coughlan, D. and Kearsley G. (1996) Does participation affect perceptions of crowding? The case of the New Zealand backcountry. In G. Kearsley (ed.) Tourism Down Under II: Towards a More Sustainable Tourism, Conference Proceedings. Dunedin: Centre for Tourism, University of Otago.

Craik, J. (1997) The culture of tourism. In C. Rojek and J. Urry (eds) Touring Cultures: Transformation of Travel and Theory (pp. 113-36). London: Routledge.

Crick, M. (1995) The anthropologist as tourist: An identity in question. In M. Lanfant, J. Allcock and M. Bruner (eds) International Tourism: Identity and Change (pp. 205-23). London: Sage.

Dann, G. (1996) The people of tourist brochures. In T. Selwyn (ed.) The Tourist Image: Myths and Myth Making In Tourism (pp. 61-82). Chichester: Wiley.

Dann, G. (1998) The pomo promo of tourism. Tourism, Culture and Communication 1,1-16.

Debord, G. (1983) Society of the Spectacle. Detroit: Red and Black.

Devlin, P.J. (1993) Outdoor recreation and environment: Towards an understanding of the use of the outdoors in New Zealand. In H.C. Perkins and G. Cushman (eds) Leisure, Recreation and Tourism (pp. 84-98). Auckland: Longman Paul.

Devlin, P.J. (1995) Outdoor recreation in New Zealand: Some introductory thoughts and beliefs. In P. Devlin, R. Corbett, and C. Peebles (eds) Outdoor Recreation In New Zealand. Volume 1: A Review And Synthesis of the Research Literature (pp. 1-16). Wellington: Department of Conservation and Lincoln University.

Devlin, P.J. and Booth, K.L (1998) Outdoor recreation and environment: Towards an understanding of the recreational use of the outdoors in New Zealand. In H.C. Perkins and G. Cushman (eds) Time Out? Leisure, Recreation And Tourism in New Zealand and Australia (pp. 109-26). Auckland: Addison Wesley Longman.

Devlin, P., Corbett, R. and Peebles, C. (eds) (1995) Outdoor Recreation in New Zealand, Volume 1: A Review and Synthesis of the Research Literature. Wellington: Department of Conservation and Lincoln University.

Frisby, D. (1992) Simmel and Since. Essays on Georg Simmel's Social Theory. London: Routledge.

Game, A. (1991) Undoing the Social: Towards a Deconstructive Sociology. Toronto: University of Toronto Press.

Goss, J. (1995) Placing the market and marketing place: Tourist advertising of the Hawaiian Islands, 1972-92. Environment and Planning D: Society and Space 11,663-88.

Greenaway, R. (1996) Managing risk - Can it be done to death? Management Magazine 43, 46-9.

Haddock, C. (1993) Managing Risks in Outdoor Activities. Wellington: New Zealand Mountain Safety Council.

Hall, C.M. (1988) Wilderness in New Zealand. Alternatives: Perspectives on Science, Technology and Environment 15 (3), 40-46.

Hall, C.M. and Kearsley, G.W. (2001)Tourism in New Zealand: An Introduction. Melbourne: Oxford University Press.

Hobbs, M. (ed.) (1996) New Zealand Outside: Annual Directory. Christchurch: Southern Alps Publications.

Higham, E.C., Kearsley, G.W. and Thyne, M.A. (1996) Crowding and encounter norms in New Zealand's conservation estate. In G. Kearsley (ed.) Tourism Down Under II: Towards a More Sustainable Tourism, Conference Proceedings. Dunedin: Centre for Tourism, University of Otago.

Higham, J.E.S. (1996a) Wilderness perceptions of international visitors to New Zealand: The perceptual approach to the management of international tourists visiting 
wilderness areas within New Zealand's conservation estate. Unpublished PhD thesis, University of Otago, Dunedin.

Higham, J.E.S. (1996b) The wilderness experiences gained by international tourists at specific sites within New Zealand's conservation estate: An examination of tourist satisfaction vis-à-vis motivations and expectations. In G. Kearsley (ed.) Tourism Down Under II: Towards a More Sustainable Tourism, Conference Proceedings. Dunedin: Centre for Tourism, University of Otago.

Higham, J.E.S. (1997a) Sustainable wilderness tourism: Motivations and wilderness perceptions held by international visitors to New Zealand's backcountry estate. In C.M. Hall, G.W. Kearsley and J. Jenkins (eds) Tourism Planning and Policy in Australia and New Zealand (pp. 75-86). Sydney: Irwin Publishers.

Higham, J.E.S. (1997b) International tourism and wilderness management in New Zealand: Managing increasing tourist demands being placed upon New Zealand's conservation estate. International Journal of Wilderness 3 (2), 27-29, 45.

Higham, J.E.S. (1997c) Perceptions of crowding held by international tourists in the New Zealand conservation estate: No single solution. In J. Higham and G. Kearsley (eds) Trails in the Third Millennium, Conference Proceedings. Dunedin: Centre for Tourism, University of Otago.

Higham, J.E.S. (1998) Sustainable wilderness tourism: The perceptual approach to wilderness management in New Zealand. Journal of Sustainable Tourism 6 (1), 26-51.

Hughes, G. (1992) Tourism and the geographical imagination. Leisure Studies 11, 31-42.

Johnston, M. (1992) Facing the challenges: Adventure tourism in the mountains of New Zealand. In B. Weiter and C. Hall (eds) Special Interest Tourism (pp. 159-70). London: Belhaven.

Johnston, B. and Edwards, T. (1994) The commodification of mountaineering. Annals of Tourism Research 21, 459-78.

Jokinen, E. and Veijola, S. (1997) The disorientated tourist: The figuration of the tourist in contemporary cultural critique. In C. Rojek and Urry, J. (eds) Touring Cultures: Transformation of Travel and Theory. London: Routledge.

Kearsley, G.W. (1990) Tourist development and wilderness management in Southern New Zealand. Australian Geographer 21 (2), 127-40.

Kearsley, G.W. (1993) Tourism and resource development conflicts on the Kawarau and Shotover rivers, Otago, New Zealand. GeoJournal 29 (3), 263-70.

Kearsley, G.W. and J.E.S. Higham (1997) Wilderness and backcountry motivations and satisfaction in New Zealand's natural areas and conservation estate. Australian Leisure (March), 30-34.

Kearsley, G.W., Kliskey, A., Higham, J.E.S. and Higham, E. (1997) Different people, different times: Different wildernesses? In J. Higham and G. Kearsley (eds) Trails in the Third Millennium, Conference Proceedings. Dunedin: Centre for Tourism, University of Otago.

Kearsley, G.W. and D. O'Neill (1994) Crowding, satisfaction and displacement: The consequences of the growing tourist use of southern New Zealand's conservation estate. In C. Ryan (ed.) Tourism Down Under (pp. 171-84). Palmerston North: Massey University.

Lefebvre, H. (1976) The Survival of Capitalism: Reproduction and Relations of Production. London: Allison and Bushby.

MacIntyre, N. and Roggenbuck, J.W. (1998) Nature/person transactions during an outdoor adventure experience: A multi-phasic analysis. Journal of Leisure Research 30 (4), 401-22.

Massey, D. (1995) Places and their pasts. History Workshop 39, 182-92.

McLauchlan, M. (1995) White water death: Why is the Shotover New Zealand's most lethal river? North and South (December), 70-81.

Meethan, K. (1996) Consuming (in) the civilized city. Annals of Tourism Research 23 (2), 322-40.

Mellor, A. (1991) Enterprise and heritage in the dock. In J. Corner and S. Horey (eds) Enterprise and Heritage: Crosscurrents of National Culture (pp. 177-92). London: Routledge. 
Morris, M. 1995 Life as a tourist object in Australia. In M. Lanfant, J. Allcock and E. Burner (eds) International Tourism: Identity and Change (pp. 96-109) London: Sage.

Munt, I. (1994) The 'other' post-modern tourism: Culture, travel and the new middle classes. Theory, Culture and Society 11, 101-23.

New Zealand Tourism Board (1998) Adventure. Wellington: NZTB.

New Zealand Tourism Board and Department of Conservation (1993) New Zealand Conservation Estate and International Visitors. Wellington: New Zealand Tourism Board and Department of Conservation.

O'Hanlon, C. (1998) Author fired by 'hobby'. The Press (edition 2) (7 July). Christchurch.

Page, S. (1989) Changing patterns of international tourism in New Zealand. Tourism Management 10, 337-41.

Page, S. and Meyer D. (1996) Tourist accidents: An exploratory analysis. Annals of Tourism Research 23 (3), 666-90.

PANZ (1997) Public Access 9, 1-12. Central Otago, New Zealand.

Pearce D.G. (1990) Tourism, the regions and the restructuring of New Zealand. Journal of Tourism Studies 1, 33-42.

Pearce D.G. (1992) Tourist Organisations. Harlow: Longman.

Pearce D.G. (1993)Domestic tourist travel patterns in New Zealand. GeoJournal 29: 225-32.

Pearce D.G. (1995) Tourism Today: A Geographical Analysis (2nd edn). Harlow: Longman.

Pearce, D.G. and Booth, K.L. (1987) New Zealand's national parks: Use and users. New Zealand Geographer 43 (2): 66-72.

Pearce D.G. and Simmons, D. (1997) Tourism in New Zealand: The Challenges of Growth in Tourism and Economic Development in Asia and Australasia. London: Cassell.

Pearce, S. (ed.) (1982) Museum Studies in Material Culture. Leicester: Leicester University Press.

Perkins, H.C. and Cushman, G. (eds) (1993) Leisure, Recreation and Tourism. Auckland: Longman Paul.

Perkins, H.C. and Cushman, G. (1998) Time Out?: Leisure, Recreation and Tourism in New Zealand and Australia. Auckland: Addison Wesley Longman.

Perkins H.C., Devlin, P.J., Simmons, D.G. and Batty, R. (1993) Recreation and tourism. In P.A. Memon and H.C. Perkins (eds) Environmental Planning in New Zealand (pp. 169-95). Palmerston North: Dunmore Press.

Perkins, H.C. and Gidlow, B. (1991) Leisure research in New Zealand: Patterns, problems and prospects. Leisure Studies 10 (2): 93-104.

Perkins, H.C. and Thorns, D.C. (2001) Gazing or performing? Reflections on Urry's tourist gaze in the context of contemporary experience in the antipodes. International Sociology 16 (2), 185-204.

Philp, J. and Mercer, D. (1999) Commodification of Buddhism in contemporary Burma. Annals of Tourism Research 26 (1), 21-54.

Pretes, M. (1995) Postmodern tourism: The Santa Claus industry. Annals of Tourism Research 22 (1), 1-15.

Ritzer, G. (1996) The McDonaldization of Society (Revised edn). Thousand Oaks, CA: Pine Forge Press.

Ritzer, G. and Liska, A. (1997) McDisneyization and post-tourism. Complementary perspectives on contemporary tourism. In S. Rojek and J. Urry (eds) Touring Cultures: Transformations of Travel and Theory (pp. 162-87). London: Routledge.

Rojek, C. (1993) Ways of Escape: Modern Transformation in Leisure and Travel. London: Macmillan.

Ryan, C. (1997) Rural tourism in New Zealand: Rafting at River Valley Ventures in the Rangitikei. In S. Page and D. Getz (eds) The Business of Rural Tourism: International Perspectives (pp. 162-87). London: International Thompson.

Schöllman, A., Perkins, H.C. and Moore, K. (2000) Intersecting global and local influences in urban place promotion: The case of Christchurch, New Zealand. Environment and Planning A 32, 55-76.

Selwyn, T. (1990) Tourist brochures as post-modern myths. Problems of Tourism 13,13-26.

Selwyn, T. (ed.) (1996) The Tourist Image: Myths And Myth Making In Tourism. Chichester: Wiley. 
Shultis, J. (1989) Image and use of New Zealand's protected areas by domestic and international visitors. GeoJournal 19 (3), 329-35.

Shultis, J. (1991) Attitudes to the natural environment, wilderness and protected areas: Historical and contemporary New Zealand analysis. Unpublished PhD thesis, Department of Geography, University of Otago.

Simmel, G. (1950) The Sociology of George Simmel (trans. K. Wolff). New York: Free Press.

Simmel, G. (1959) A Collection of Essays (trans. K. Wolff). Columbus, OH: Ohio State University Press.

Simpson, J. (1998) Dark Shadows Falling. London: Vintage.

Squire, S. (1994) Accounting for cultural meanings: The interface between geography and tourism studies re-examined. Progress in Human Geography 18, 1-16.

Stymeist, D.H. (1996) Transformation of Vilavilairevo in tourism. Annals of Tourism Research 28, 1-18.

The New Zealand Way (1993) The New Zealand Way. Wellington: NZW.

The Press (2000a) Safety record risk to tourism. (9 September), 6.

The Press (2000b) Jetboat industry to be reviewed. (27 September), 12.

Tourism New Zealand (2002) International visitor surveys - activities undertaken and attractions visited. On WWW at http: / / www.tourisminfo.govt.nz.

Urry, J. (1990) The Tourist Gaze. London: Sage.

Uzell, D. (1984) An alternative structuralist approach to the psychology of marketing. Annals of Tourism Research 11,79-99.

Veal, A.J., Gidlow, B. and Perkins, H.C. (1998) Interpreting leisure participation in New Zealand and Australia. In H.C. Perkins and G. Cushman (eds) Time Out? Leisure, Recreation And Tourism in New Zealand and Australia (pp. 64-85). Auckland: Addison Wesley Longman.

Walle, A. (1997) Pursuing risk or insight - Marketing adventures. Annals of Tourism Research 24, 265-82.

Wane, J. (1995/6) In search of the rush. Pacific Way (December 1995/January 1996), 96-102.

Watson, G.L. and Kopachevsky, J.P. (1994) Interpretations of tourism as commodity. Annals of Tourism Research 24 (4), 643-60.

\section{The Authors}

Paul Cloke is Professor of Geography at the University of Bristol (University Road, Bristol BS8 1SS, United Kingdom, P.Cloke@Bristol.ac.uk). His research interests include the economic restructuring and cultural transformation in rural areas.

Harvey Perkins is Associate Professor in the Environment, Society and Design Division at Lincoln University (PO Box 84, Lincoln University, Canterbury, New Zealand, Perkins@Lincoln.ac.nz). His research interests include the social geography and sociology of human settlement, the city, leisure and tourism. 